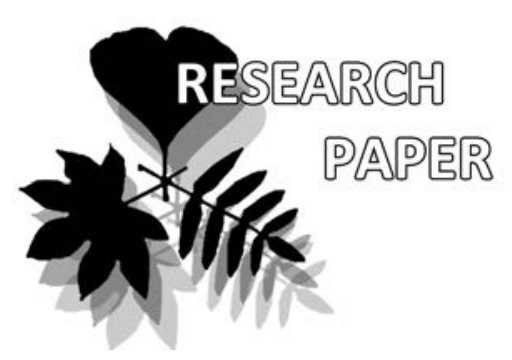

Eugene S. Popov

e-mail: epopov@binran.ru

Sergey V. Chesnokov ${ }^{1,2 *}$

e-mail: lukinbrat@mail.ru

Liudmila A. Konoreva ${ }^{2,3}$

e-mail: ajdazapov@yandex.ru

Alexander K. Ezhkin ${ }^{4}$

e-mail: ezhkin@yandex.ru

Irina S. Stepanchikova ${ }^{1,5}$

e-mail: stepa_ir@mail.ru

Ekaterina S. Kuznetsova ${ }^{1,5}$

e-mail: igel_kuzn@mail.ru

Dmitry E. Himelbrant $t^{1,5}$

e-mail: d_brant@mail.ru

Irina A. Galanina

e-mail: gairka@yandex.ru

Svetlana I. Tchabanenko ${ }^{7 \dagger}$

${ }^{1}$ Komarov Botanical Institute RAS, St. Petersburg, 197376, Russia

${ }^{2}$ Botanical Garden-Institute FEB RAS,

Vladivostok, Russia

${ }^{3}$ Polar-Alpine Botanical Garden-Institute of the Kola Science Centre RAS,

Kirovsk, Russia

${ }^{4}$ Institute of Marine Geology and

Geophysics FEB RAS,

Yuzhno-Sakhalinsk, Russia

${ }^{5}$ St. Petersburg State University,

St. Petersburg, Russia

${ }^{6}$ Federal Scientific Center of East Asian Terrestrial Biodiversity FEB RAS,

Vladivostok, 690022, Russia

${ }^{7}$ Sakhalin Branch of Botanical GardenInstitute FEB RAS, Vladivostok, Russia † Deceased

* corresponding author

Manuscript received: 08.10.2019 Review completed: 12.02 .2020 Accepted for publication: 20.05.2020 Published online: 23.05.2020

\section{Stictis s.l. (Ostropales, Ascomycota) in the Russian Far East}

Eugene S. Popov ${ }^{1}$, Sergey V. Chesnokov ${ }^{1,2 *}$, Liudmila A.

Konoreva ${ }^{2,3}$, Alexander K. Ezhkin ${ }^{4}$, Irina S. Stepanchikova ${ }^{1,5}$,

Ekaterina S. Kuznetsova ${ }^{1,5}$, Dmitry E. Himelbrant ${ }^{1,5}$, Irina A. Galanina ${ }^{6}$ \& Svetlana I. Tchabanenko ${ }^{7 \dagger}$

\section{A B S T R A C T}

This paper summarizes literature data and new information on the geographical distribution and ecology of Stictis and closely related genera in Russia. Stictis sphaeroboloides is reported as new to Eurasia; Carestiella socia and Stictis populorum are new to Asia, $S$. carnea is new to Russia, and $S$. radiata is new to the Russian Far East. New data on distribution and ecology of Carestiella socia and five Stictis species are provided along with a comprehensive key for all species of Stictis s.l. sensu Wedin et al. (2006) known in Russia and nearby areas. Our research clearly shows importance of the collaboration between mycologists and lichenologists to study trophically complex taxa and to obtain the most complete knowledge about fungal diversity.

Ke y word s : lichenized fungi, saprotrophic fungi, Sakhalin, Kamchatka, Primorsky Territory, Kuril Islands

\section{P E 3 Ю M E}

Попов Е.С., Чесноков С.В., Конорева А.А., Ёжкин А.К., Степанчикова И.С., Кузнецова Е.С., Гимельбрант А.Е., Галанина И.А., Чабаненко С.И. Род Stictis s.1. (Ostropales, Ascomycota) на Российском Аальнем Востоке. Впервые представлен об̆зор по роду Stictis s.l. sensu Wedin et al. (2006) Аля российского АаАьнего Востока. Состав ен ключ Аля виАов, известных в России. Представлены новые Аанные о распространении и экомогии Carestiella socia и пяти виАов из рода Stictis. Stictis sphaeroboloides впервые приводится Аля Евразии. Carestiella socia и Stictis populorum явАяются новыми видами Аля Азии; S. carnea впервые приводится Аля России, S. radiata приводится зАесь как новый вид Аля российского Аальнего Востока. Наше исследование ясно показывает важность сотрудничества между микологами и Аихенологами Аля изучения трофически сложных таксонов и получения наиболее полных знаний о разнообразии грибов.

КАючевые слова: Аихенизированные грибы, сапротрофные грибы, Сахалин, Камчатка, Приморский край, Курильские острова

Stictis s.l. as circumscribed by Wedin et al. (2006) includes taxa from at least three ostropalean genera (Stictis s.str., Carestiella, and Schizoxylon pro parte). Within Stictis s.l. some taxa have shown facultative lichenization where the fungus may either persist as saprotroph or be lichenized, apparently depending on its substrate, i. e. bark or wood (Wedin et al. 2004).

Four Schizoxylon species, five Stictis species and one Ostropa species were reported from Russia before. Their distribution by large geographical regions (adopted after Czerepanov 1995) is as follows:

European Part of Russia. Five species of Stictis and one species of Schizoxylon are known: Schizoxylon berkeleyanum (Durieu et Lév.) Fuckel (Jaczewski 1896), Stictis brunnescens Gilenstam et al. (Wedin et al. 2006, Notov et al. 2011, Kuznetsova et al. 2012), S. mollis Pers. (Jaczewski 1895, Tranzschel 1905, Tranzschel \& Serebrianikow 1912, Popov 2012, Muchnik et al. 2019), S. phragmitis Lobik (Lobik 1928), S. populorum (Gilenstam) Gilenstam (Hermansson et al. 2006, Urbanavichus 2014), S. radiata Pers. (Martius 1817, Weinmann 1828, Karsten 1866, Vasil'eva 1939, Sirko 1976, Vaasma et al. 1986, Urbanavichene 2011, Kuznetsova et al. 2012, Popov \& Volobuev 2014, Churakov et al. 2015, Huseyin et al. 2016, Himelbrant et al. 2017).

Caucasus. Three species were previously reported: Schizoxylon alboatrum (Urbanavichus \& Urbanavichene 2017), Stictis brunnescens Gilenstam et al. (Urbanavichus \& Urbanavichene 2015), and S. radiata Pers. (Vaasma et al. 1986, Urbanavichene \& Urbanavichus 2014). 
Western and Eastern Siberia. Only Stictis mollis has been known to occur in Siberia since 1880 (Thümen, as $S$. ollaris Wallr.). Konoreva et al. (2016) summarized data on the distribution and ecology of Stictis s.l. in Russia and added Schizoxylon albescens Gilenstam et al., Stictis brunnescens and $S$. radiata from Altai Mts. and Eastern Siberia.

Russian Far East. Three species were previously reported: Stictis mollis, Schizoxylon berkeleyanum and Ostropa barbara (Koval' 1972) from the Primorye Territory, and Schizoxylon hemisphaericum (Fr.) DiCosmo et al. known only from the type locality in Kamchatka (Fries 1823, DiCosmo et al. 1984).

Thus, most of known records originate from European part of Russia, while the diversity and distribution of Stictidaceae. in Asian part remain poorly understood, and only four species were known from the Russian Far East before our research.

\section{MATERIAL AND METHODS}

The present study is based on the specimens collected by the authors between 2005 and 2018 in various regions of the Russian Far East. The data from the Pskov Region and Karachayevo-Circassian Republic were used to clarify the distribution of the species in Russia. The specimens are deposited in the lichen and fungal subdivisions of the herbarium of the Komarov Botanical Institute RAS, St. Petersburg, Russia (LE), also in the herbaria of St. Petersburg State University, St. Petersburg, Russia (LECB), Polar-Alpine Botanical Garden-Institute of the KSC RAS, Kirovsk, Russia (KPABG), University of Helsinki, Helsinki, Finland $(\mathrm{H})$, Institute of Marine Geology and Geophysics FEB RAS, Yuzhno-Sakhalinsk, Russia (SAK) and Sakhalin Branch of Botanical Garden-Institute FEB RAS, YuzhnoSakhalinsk, Russia (SAKH).

The material was examined at The Core Facility Center "Cell and Molecular Technologies in Plant Science" at the Komarov Botanical Institute using standard microscopic techniques (Smith et al. 2009). Photographs of the species were made using AxioCam MRc5 digital camera mounted on Stemi-2000 CS light microscope. The distribution map was prepared using MapInfo GIS software. Geographical coordinates are given in spatial reference system WGS 1984.

Abbreviations of authors in text: EP = Eugene S. Popov, $\mathrm{SCh}=$ Sergey V. Chesnokov, LK = Liudmila A. Konoreva, $\mathrm{AE}=$ Alexander K. Ezhkin, IS = Irina S. Stepanchikova, EK = Ekaterina S. Kuznetsova, DH = Dmitry E. Himelbrant, IG = Irina A. Galanina.

\section{RES U LTS}

Altogether 21 specimens were studied, and 7 species of Stictis s.l. were revealed in the Russian Far East. Carestiella socia, Stictis populorum, and S. sphaeroboloides are new to Asia, $S$. carnea is new to Russia, and $S$. radiata is new to the Russian Far East.

To facilitate the progress in the studies of diversity and distribution of Stictidaceae in Russia we provide an identification key for the filiform-spored epixylic and epiphytic species of Stictis and morphologically similar genera known to occur in the country. Short descriptions, differences from the related species, notes on ecology and distribution are given for species found in the Far East.

\section{Key to the epixylic and epiphytic filiform-spored species of Stictidaceae in Russia}

All species mentioned in the key are known from Russia; for the species which are not yet reported from Russian Far East but expected to be found there the notes on distribution are given in brackets.

1. Apothecia opening at maturity by a rounded pore or irregular fissures ........................................................................... 2 - Apothecia opening at maturity by a transverse slit ......... 13

2. Periphysoids \pm distinct; apothecial margin with distinct crystalline inclusions; ascospores not disarticulating into part-spores (genus Stictis) ......................................................... 3 - Periphysoids absent or indistinct; apothecial margin usually without crystalline inclusions (but see Schiroxylon alboatrum), sometimes with crystalline pruina on outer surface; ascospores disarticulating or not ............................................ 9

3. Hymenium remaining covered by crystalline layer for a long time after eruption trough the host tissues .....................
Stictis sphaeroboloides

- Hymenium soon opening by a pore ....................................... 4

4. Disc ochraceous, glossy, never pruinose ............................ 5

- Disc brown, or grey to black, \pm dull, often pruinose ....... 7

5. Margin partly brown in section ............ Stictis brunnescens - Margin colourless in section ................................................... 6

6. Ascospores 3-3.5 $\mu \mathrm{m}$ broad, distinctly tapered below; individual cells 3-4 $\mu \mathrm{m}$ long .............................. Stictis carnea - Ascospores 2-2.5 $\mu \mathrm{m}$ broad, not or slightly tapered; individual cells 4-7 $\mu \mathrm{m}$ long ............................ Stictis radiata

7. Ascospores more than $3 \mu \mathrm{m}$ broad ....... Stictis populorum - Ascospores less than $3 \mu \mathrm{m}$ broad .......................................... 8

8. Ascospores longer than $100 \mu \mathrm{m}$; on wood and bark .......... . - Ascospores shorter than $100 \mu \mathrm{m}$; on stems of Phragmites .....

[so far known only from the type locality in Kalmykia] 9. Ascospores with average length less than $100 \mu \mathrm{m}, 3$ - to 7-septate; asci less than $150 \mu \mathrm{m}$ long, multispored

Carestiella socia

- Ascospores and asci longer on average; ascospores with more than 10 septa; asci initially 8-spored, when mature filled with numerous part-spores

10. Ascospores 100-130 $\times 5-6 \mu \mathrm{m}$, part-spores 1-celled, globose to discoid, 3-7 $\times 5-6 \mu \mathrm{m}$; apothecia black ................... - Ascospores more than $150 \mu \mathrm{m}$ long and up to $2.5 \mu \mathrm{m}$ broad, part-spores, if present, 1 - to multiseptate, oblong; apothecia with grayish, white or yellowish pruina .............. 11

11. Excipular pigment dissolving in $\mathrm{KOH}$ and staining the medium bright yellow; ascospores regularly disarticulating into two-celled part-spores; predominantly on large herbaceous stems...

Schizoxylon berkeleyanum

- Excipular pigment not reacting with $\mathrm{KOH}$; ascospores disarticulating or not; on wood and bark

12

12. Ascospores ca 150-270 $\times 1.5-2.5 \mu \mathrm{m}$, disarticulating into 2-15-septate part-spores; asci ca 200-280 $\mu \mathrm{m}$; margin without crystalline inclusions ............. Schizoxylon albescens

[Palearctic taxon]

- Ascospores longer, not regularly disarticulating into part-spores; asci longer than $300 \mu \mathrm{m}$; margin with crystals Schizoxylon alboatrum [Holarctic taxon]

13. Apothecia deep immersed, hockey stick-shaped in longitudinal section, with longer axis subparallel to substrate surface ................... Robergea cubicularis [Holarctic taxon] - Apothecia erumpent, \pm rounded in longitudinal section, oriented perpendicular to substrate surface

Ostropa barbara 

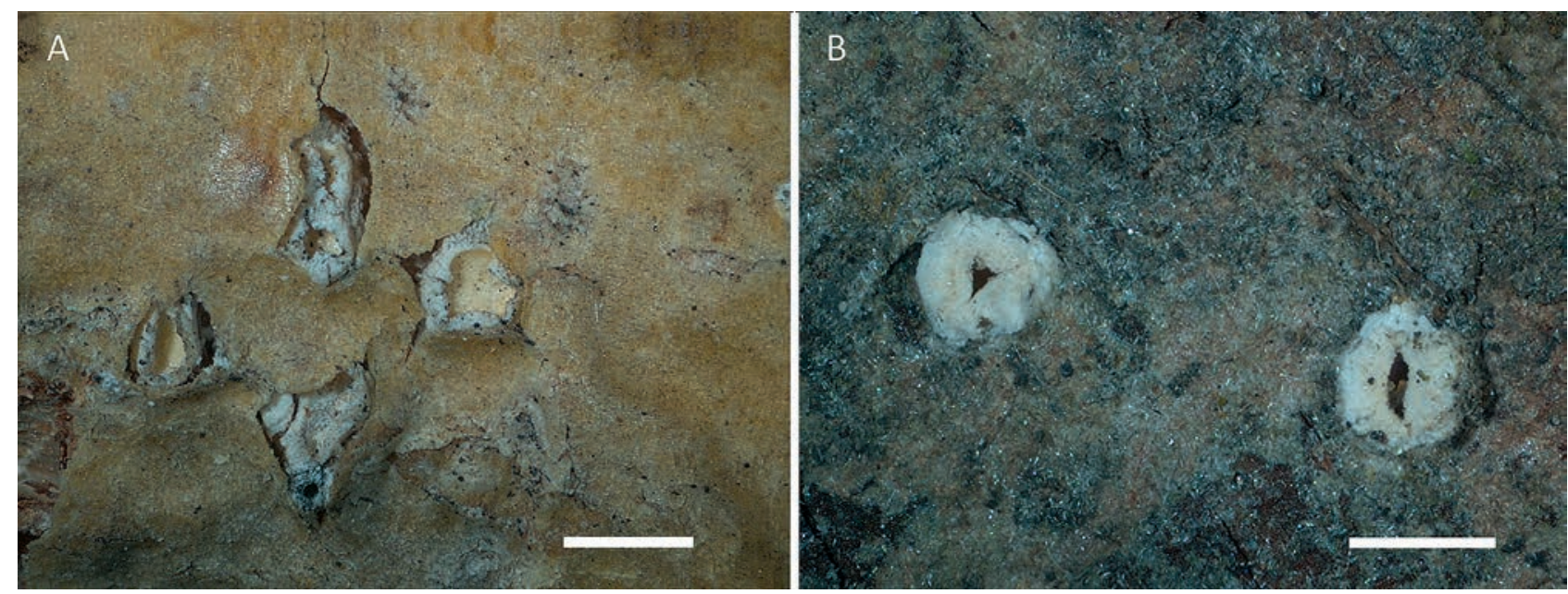

Figure 1 A - Carestiella socia Bres.; B - Stictis carnea Seaver \& Waterston. Scale bar A, B = 1 mm

Carestiella socia Bres., Malpighia 11(6-8): 274. 1897 (Fig. 1A, 2)

This species is easily recognized by its multispored asci, relatively short, often falcate or sigmoid ascospores with 3-7 transverse septa, and peculiar structure of the excipular margin, which is composed of loosely interwoven brown thick-walled hyphae without crystalline inclusions. The only known specimen of C. socia in Russia was collected during Ryabushinsky's Kamchatka Expedition (1908-1909), but remained unidentified and was not mentioned in the expedition report (Tranzschel 1914). It fits well the detailed description of the species given by Wedin et al. (2006). In the material studied asci were predominately 16 -spored, ca 80-90 $\times 10-15 \mu \mathrm{m}$. Ascospores 38-50 × 2-2.5 $\mu \mathrm{m}$, with 3-7 septa.

Ecology. Saprotrophic on wood and bark of Populus and Salix spp., facultatively lichenized according to Wedin et al. (2006).

Distribution. This is the first report of Carestiella socia from Russia and Asia. Previously the species was reported from Europe (Italy, Sweden, Norway), and North America (Wedin et al. 2006).

Specimens examined: KAMCHATKA TERRITORY, Yelizovo District, between Malka and Ganaly, near the Shestaya River, on bark of Salix sp. [according to the label on 'vetla', a Russian name for some species of Salix subgen. Salix], VI.1909, V. P. Savicz s. n. (LE 172078).

Schizoxylon hemisphaericum (Fr.) DiCosmo, Nag Raj \& W.B. Kendr., Can. J. Bot. 61(1): 44. 1983

Schizoxylon hemisphaericum was described by Fries (1823) as Phacidium hemisphaericum Fr. based on single collection made by Wormskjold in Kamchatka. DiCosmo et al. (1984) studied the holotype which is kept now in Fries's Herbarium in Uppsala (UPS) and argued that this species should be placed in Schizoxylon. They also provided a full description and illustrations of the type material.

Ecology. Saprotrophic on bark and wood of Betula.

Distribution: Known only from the type locality.

Stictis carnea Seaver \& Waterston, Mycologia 33(3): 311. 1941 (Fig. 1B, 2)

Stictis carnea has apothecia with a general appearance similar to those of $S$. radiata, but differs in definitely broader ascospores

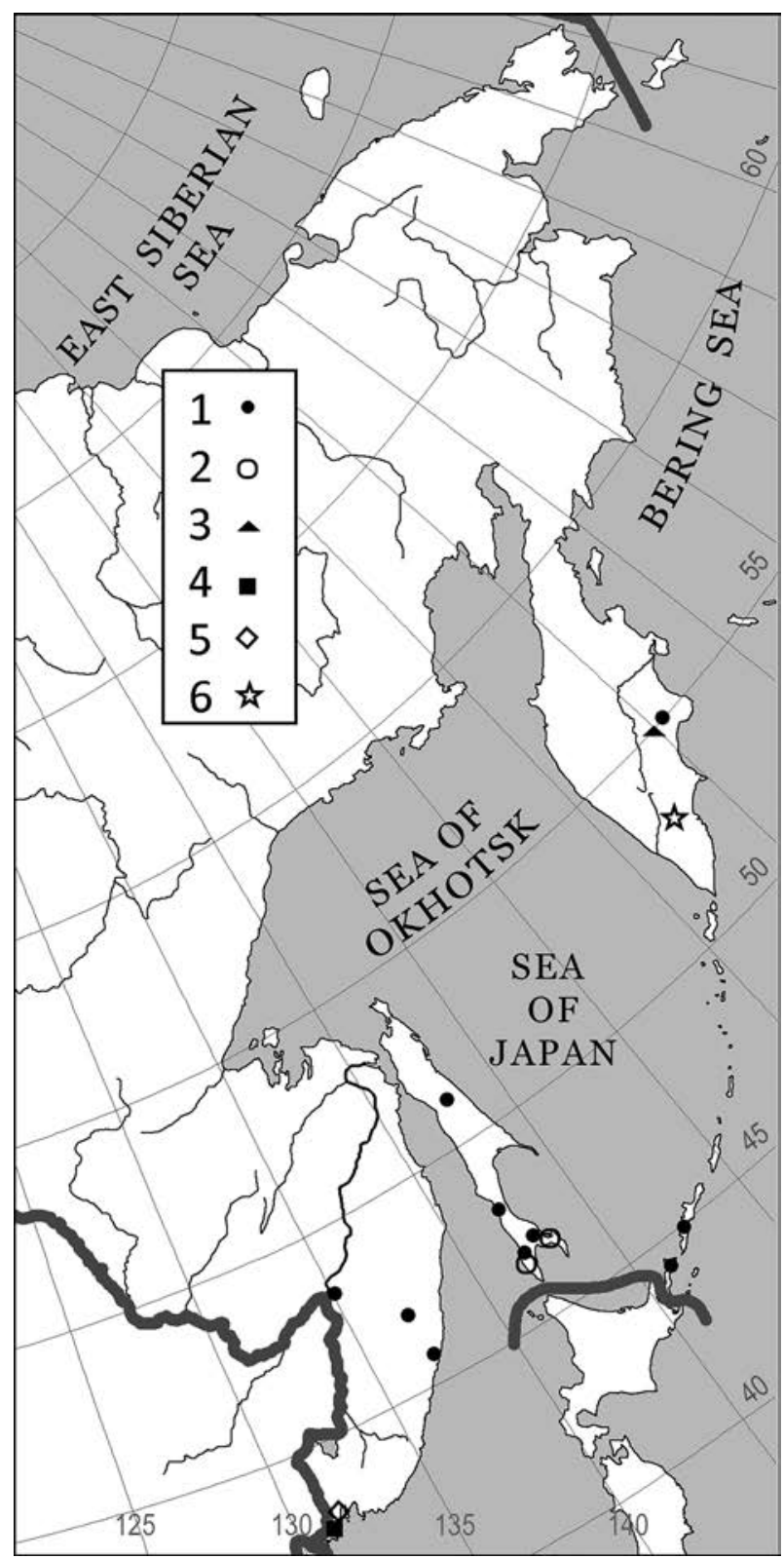

Figure 2 The distribution of genera Stictis and Carestiella in the Russian Far East: 1 - Stictis radiata Pers., $2-S$. mollis Pers., $3-S$. populorum (Gilenstam) Gilenstam, $4-S$. carnea Seaver \& Waterston, 5 - S. sphaeroboloides (Schwein.) Ellis, 6 - Carestiella socia Bres. 
with short, isodiametric to discoid individual cells. For a full description and illustrations, refer to Sherwood (1977).

Ecology. Saprotrophic on various woody substrates.

Distribution. Widely distributed in tropical areas. Known from Asia (Hong Kong, Philippines, Sri Lanka), Africa, South America, New Zealand (Sherwood 1977, Johnston 1983, Whitton et al. 1999). The record from this survey is the most northern known occurrence of the species (Fig. 2). This, however, is in good agreement with the relatively high diversity of taxa with tropical and subtropical biogeographic affinities in the flora of the southern Primorye Region of the Russian Far East (Kozhevnikov \& Kozhevnikova 2014).

Specimens examined: PRIMORYE TERRITORY, Khasansky District, Kedrovaya Pad Nature Reserve, the Kedrovaya River valley, 4306'00.5"N 131³3'32.3"E, on bark of Acer sp. 19.VIII.2005, EP (LE 323496).

Stictis mollis Pers., Mycol. eur. (Erlanga) 1: 337.1822 (Fig. 2) Stictis mollis is one of the three Stictis species (together with S. confusum and $S$. populorum), shown to occur on wood as a saprotroph, and on bark when lichenized (Wedin et al. 2006).

Stictis mollis is easily distinguished from the two other Stictis species with distinctly brown margins $(S$. confusum and $S$. populorum) by the comparatively narrow spores and the olivaceous, amorphous pigmentation of the uppermost part of the paraphyses (Wedin et al. 2006).

Ecology. According to Wedin et al. (2006) the saprotrophic form of the species inhabits decorticated thin dead branches or twigs of Populus tremula L. and Salix caprea L. in Sweden, Norway and Germany, while the lichenized form is usually developed on young, thin smooth-barked Populustrunks in Sweden and Norway. The specimen reported by Muchnik et al. (2019) belongs to the lichenized form and grows on bark of young Acer sp. The two specimens examined as part of this study were collected on old, coarse bark of Populus maximowiczii Henry in mixed forests, and were not lichenized.

Distribution. The species is known from Greenland (Rostrup 1891), Norway, Sweden, Germany (Wedin et al. 2006), Spain (Malençon \& Bertault 1972), Greece (Zervakis et al. 1999), Ukraine (Dudka et al. 2009), and North Africa (Malençon \& Bertault 1969). In Russia it is known from the Ryazan Region (Muchnik et al. 2019), Novgorod Region (Popov 2012), Smolensk Region (Jaczewski 1895), Yaroslavl Region (Tranzschel \& Serebrianikow 1912), Republic of Crimea (Tranzschel 1905), Krasnoyarsk Territory (Thümen 1880), Primorye 'Territory (Koval' 1972), Pskov Region, Karachayevo-Circassian Republic (this paper).

Specimens examined: SAKHALIN REGION, Sakhalin Island, Korsakov District, Tunaicha Lake surroundings, 46 48'07.4"N 14306'15.7"E, mixed forest, on bark of Populus maximowiczii, 26.X.2017, AE (SAK 1675, LE); ibid., Nevelskiy District, Shebunino village surroundings, $46^{\circ} 26^{\prime} 09.2^{\prime \prime} \mathrm{N} 141^{\circ} 54^{\prime} 12.5^{\prime \prime} \mathrm{E}$, alt. $13 \mathrm{~m}$, mixed forest, on bark of Populus maximowiczii, 17.V.2016, AE (SAK 1676, LE).

Additional specimens examined: PSKOV REGION, Loknyanskiy District, Bashovo, 56³9'31.0"N 30¹0'15.7"E, on bark of Ulmus laevis Pall., 17.VIII.2011,
EP(LE 247491); ibid., Skokovo, 56³9'45.9"N 3008'50.5"E, on wood of Populus longifolia Fisch. ex Loudon, 28.VII.2011, EP (LE 247555); Ivantsevo, 56³8'47.4"N 2954'38.7"E, on wood of Salix caprea L., 13.VIII.2011, EP (LE 247493); ibid., Polistovsky Nature Reserve, Korolyova Borina $9 \mathrm{~km} \mathrm{~N}$ of Gogolevo, 5704'40.5"N 30³2'52.0"E, on wood of Populus tremula L., 19.IX.2018, EP (LE 323495). KARACHAYEVOCIRCASSIAN REPUBLIC, Karachayevsky District, Teberdinsky Nature Reserve, environs of Dombay, Amnauz

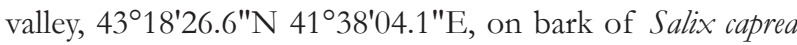
L., 14.VIII.2012, EP (LE 247819).

Stictis populorum (Gilenstam) Gilenstam, Lichenologist 37(1): 74.2005 (Fig. 2)

A detailed description of this species and differences from the closely related species was given by Wedin et al. (2006).

Ecology. A saprotroph on Populus wood, particularly on decorticated branches still remaining on the living trunks, or as a lichen in and around cracks in the bark of Populus spp. in northern Scandinavia (Wedin et al. 2006). Kamchatian specimen were found on twigs of $P$. tremula in the young spruce forest.

Distribution. In Russia this species was reported from the Murmansk Region (Urbanavichus 2014) and Republic of Komi (Hermansson et al. 2006). Originally known from Sweden (Wedin et al. 2006).

Specimen examined: KAMCHATKA TERRITORY, Eastern Kamchatka, Mil'kovo District, Kronotsky Nature Reserve, Levaya Shchapina River basin, right bank of the Levaya Shchapina River opposite to the mouth of the Ipuin River, on

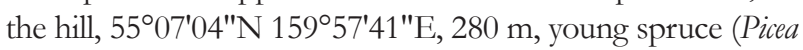
jezoensis Carrière subsp. ajanensis (Fisch. ex Carrière) Silba) forest with sparse grass and traces of burn, on dead twig of Populus tremula, 14.VIII.2009, DH, IS, K-15-09 (H).

Stictis radiata Pers., Observ. mycol. (Lipsiae) 2: 73.1800 (Fig. 2)

A detailed description of the species and differences from the closely related taxa was provided by Wedin et al. (2006).

Ecology. The species has wide ecological niche (Wedin et al. 2006). In the Far East it is distributed in different types of forests, mainly near the water (along rivers, creeks and

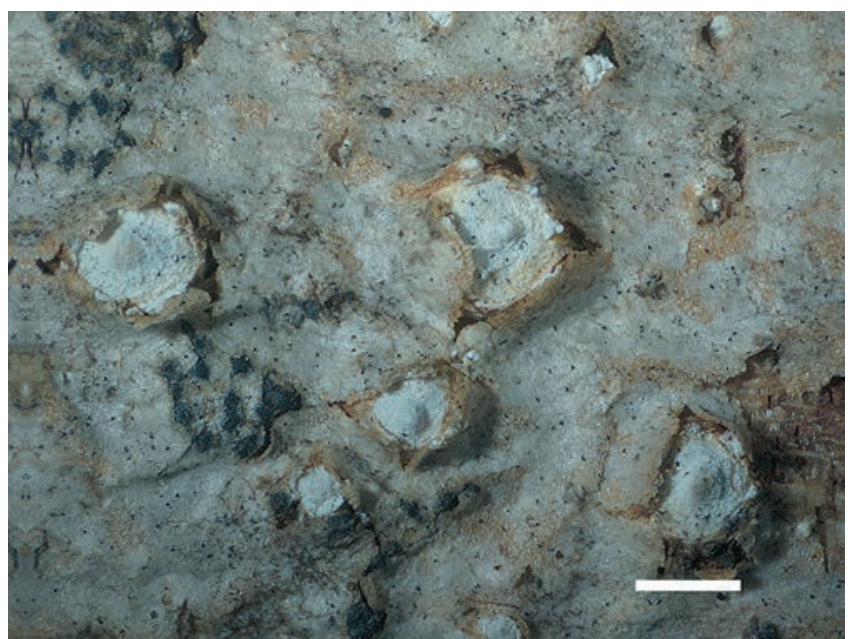

Figure 3 The apothecia of Stictis sphaeroboloides (Schwein.) Ellis. Scale bar $=1 \mathrm{~mm}$. 
lakes), on bark or wood of Picea, Pinus, Populus, Ulmus, Salix and Sorbus spp.

Distribution. A rather common species in Russia, S. radiata was reported from Murmansk Region (Karsten 1866, Konoreva et al. 2016), Leningrad Region (Kuznetsova et al. 2012, Himelbrant et al. 2017), St. Petersburg (Weinmann 1828), Moscow (Martius 1817), Ulyanovsk Region (Churakov et al. 2015, Huseyin et al. 2016), Kaluga Region (Popov \& Volobuev 2014), Chelyabinsk Region (Urbanavichene 2011), Sverdlovsk Region (Sirko 1976), Krasnodar Territory (Vasil'eva 1939, Urbanavichene \& Urbanavichus 2014), Republic of Adygea (Vaasma et al. 1986), Krasnoyarsk Territory, Trans-Baikal Territory and Yakutia (Konoreva et al. 2016), Karachayevo-Circassian Republic (this paper). Cosmopolitan species widely distributed in Eurasia, Africa, North and South America Australia, and New Zealand (Rodway 1924, Sherwood 1977, Johnston 1983, Gamundí et al. 2004).

Specimens examined: KAMCHATKA TERRITORY, Eastern Kamchatka, Mil'kovo District, Kronotsky Nature Reserve, Levaya Shchapina River basin, $2.3 \mathrm{~km} \mathrm{SE}$ to the mouth of the Ipuin River, right bank of the Ipuin River, 5506'05"N 15959'22"E, 280 m, Populus suaveolens Fisch. and graminoid dominated flood-plain forest near the river, on branch of Picea jezoensis subsp. ajanensis, 10.VIII.2009, DH, IS, K-10-09 (H); ibid., SW part of Askhachny Ridge, $2.2 \mathrm{~km}$ $\mathrm{N}$ to the mouth of the Ipuin River, SSE slope, $55^{\circ} 08^{\prime} 07^{\prime \prime} \mathrm{N}$ 159 57'23"E, $300 \mathrm{~m}$, spruce (Picea jezoensis subsp. ajanensis) forest with green mosses, on branch of Picea jezoensis subsp. ajanensis, 11.VIII.2009, DH, IS, K-11-09 (H). PRIMORYE TERRITORY, Terney District, Sikhote-Alin, valley of the Taratay creek, $45^{\circ} 42^{\prime} 00.4^{\prime \prime} \mathrm{N} 136^{\circ} 39^{\prime} 48.6^{\prime \prime E}$, Pinus koraiensis Siebold et Zucc. dominated forest mixed with broadleaved trees, on wood, 13.08.2010, EK, Prim-22 (LECB); ibid., Krasnoarmeysky District, neighborhood of the Tayozhny village, 4541'22.6"N 136²1 '12.5"E, cedar-spruce forest on the northern slope, on bark of Picea sp., 06.VII.2011, IG, T. 412 (KRABG); KHABAROVSK TERRITORY, Khabarovsk District, Bolshekhekhtsirsky Reserve, Bykov River, neighborhood of the cordon Bychikha, 48 14'17.3"N $134^{\circ} 48^{\prime} 49.8^{\prime \prime E}, 283 \mathrm{~m}$, coniferous-deciduous forest, on branch of Picea sp., 29.IX.2018, SCh (LE); ibid., neighborhood of the cordon Sosninsky, Sosninsky creek, 4814'16.8"N 13446'41.7"E, $408 \mathrm{~m}$, Ulmus sp.-Betula sp. forest with Picea sp., on branch of Picea sp., 01.X.2018, SCh (LE). SAKHALIN REGION, Sakhalin Island, Dolinsky District, neighborhood of the Sokol settlement, Belaya River, 47¹5'14.5"N 14248'21.9"E, 99 m, Salix sp. floodplain forest, on bark of Salix sp., 08.V.2017, LK (LE); ibid., $47^{\circ} 15^{\prime} 13.0^{\prime \prime} \mathrm{N} 142^{\circ} 48^{\prime} 12.0^{\prime \prime} \mathrm{E}, 87 \mathrm{~m}$, on wood of Salix sp., 08.V.2017, SCh (LE); ibid., 47015'00.3"N 142²7'33.3" E, alt. $56 \mathrm{~m}$, riparian forest, bark of Salix udensis Trautv., 08.V.2016, AE (SAK 1301, 1303, 1304, 1305); ibid., Yuzhno-Sakhalinsk city surroundings, Mitsul' Mountain, $47^{\circ} 03^{\prime} 02.3^{\prime \prime} \mathrm{N}$ $142^{\circ} 30^{\prime} 39.5^{\prime \prime} \mathrm{E}$, alt. $536 \mathrm{~m}$, dark coniferous forest with Betula ermanii Cham., on bark of Sorbus commixta Hedl., 26.V.2012, AE (SAK 1296); ibid., Tomarinsk District, near Ainskoe Lake, $48^{\circ} 27^{\prime} 03.7^{\prime \prime} \mathrm{N} 142^{\circ} 04^{\prime} 01.6^{\prime \prime} \mathrm{E}$, alt. $4 \mathrm{~m}$, mixed forest, on bark of Picea jezoensis (Siebold \& Zucc.) Carrière, 15.IX.1997, ST (SAKH); ibid., Tymovskiy District, Pilenga River, $51^{\circ} 04^{\prime} 52.4^{\prime \prime} \mathrm{N} 142^{\circ} 44^{\prime} 14.5^{\prime \prime} \mathrm{E}$, alt. $119 \mathrm{~m}$, riparian forest, bark of Populus maximowiczii, 04.VI.2017, AE (SAK 1297, 1298, 1299); ibid., 51 $01^{\prime} 45.7^{\prime \prime} \mathrm{N} 142^{\circ} 50^{\prime} 33.7^{\prime \prime E}$, alt. $154 \mathrm{~m}$, riparian forest, on bark of Ulmus laciniata Trautv., 05.VI.2017, AE (SAK 1302); Iturup Island, Ostrovnoy Reserve, Odessky

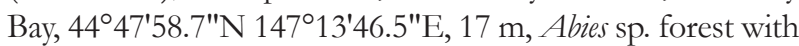
Sasa kurilensis (Rupr.) Makino \& Shibata, on decayed wood of Sorbus sp., 13.VIII.2017, LK (LE); Kunashir Island, proximity of Lagunnoe Lake, $44^{\circ} 02^{\prime} 50.2^{\prime \prime} \mathrm{N} 145^{\circ} 46^{\prime} 01.6^{\prime \prime} \mathrm{E}$, alt. 79 m, old-growth mixed coniferous/broadleaved forest, on bark of Ulmus laciniata, 08.I.2017, AE (SAK 1300).

Additional specimens examined: KARACHAYEVOCIRCASSIAN REPUBLIC, Karachayevsky District, Teberdinsky Nature Reserve, environs of Dombay, Amnauz

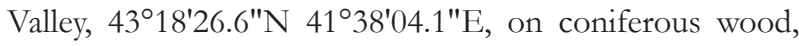
14.VIII.2012, EP (LE 247817); ibid., on wood of Picea orientalis (L.) Peterm., 14.VIII.2012, EP (LE 247818).

Stictis sphaeroboloidea (Schwein.) Ellis, N. Amer. Fung., Ser. 1: no. 463. 1881 (Fig. 2, 3)

This species is well characterized by erumpent apothecia that remain closed by crystalline layer of ascomatal wall for a long time, and paraphyses with inflated brown apices.

Ecology. Saprotrophic on wood and bark of deciduous trees and shrubs, typically on Quercus (Sherwood 1977).

Distribution. The species was previously known from eastern North America, where it is quite common (Sherwood 1977). The record in Russian Far East thus is another example of a 'Grayan disjunction' between eastern Asia and eastern North America, which is well known in plants $(\mathrm{Li}$ 1952, Graham 1972, Davidse 1983, Wen 1999), and not uncommon in fungi (Culberson 1972, Wu \& Mueller 1997, Kovacs et al. 2008, Vasilyeva \& Stephenson 2010).

Specimens examined: PRIMORYE TERRITORY, Khasansky District, Kedrovaya Pad' Nature Reserve, the Kedrovaya River valley, near the mouth of the 1 st Zolotoy creek, 4306'31.9"N 131³1'59.3"E, on bark of Fraxinus mandshurica Rupr., 20.VIII.2005, EP (LE 323498).

\section{DISCUSSION}

Symbiotic associations with photosynthetic partners most probably were established and lost independently multiple times in different clades of Ascomycota (Hawksworth 2015), thus many ascomycete taxa include both lichenized and nonlichenized species. The family Stictidaceae is one of the textbook examples of this complexity. It accommodates 54 lichenized species from 13 genera (Lücking et al. 2016) and a number of nonlichenized (Wedin et al. 2005). The level of lichenization in the family varies widely not only at the genus level, but also at the species level, i. e. lichenized and non-lichenized individuals can be found even within one fungal species. This results in lack of attention or neglecting the whole family or certain genera either by lichenologists or by mycologists. In traditional scientific practice the collections of lichenized and nonlichenized species from the same families or even genera are kept in different herbarium compartments (lichenological and mycological, respectively), many specialists poorly know 'alien taxa', 'alien herbaria', and 'alien literature' or even are not interested in 'mixed taxa'. Predictable result of this 'independence' is the 
producing of 'new records', already successfully published before, as well as lack of our knowledge on such groups.

Our present paper summarizes data on known diversity of the closely related (Wedin et al. 2005) genera Carestiella, Schizoxylon, and Stictis in Russian Far East. Some data are based on recent collections of the authors (Stictis carnea, S. mollis, S. populorum, S. radiata, S. sphaeroboloides), others are received from the revision of the herbarium samples (Carestiella socia), or previously published in mycological papers, like Schizoxylon hemisphaericum (DiCosmo et al. 1984). However, Russian Far East is a huge territory, which still remains underexplored, so far we expect that other species can be found there in course of further research. Therefore, our key includes all the species known in Russia at present time, and hopefully can be used in wider territory than Far East only.

The species discussed here are known to have different level of lichenization: saprotrophic - Schizoxylon hemisphaericum (DiCosmo et al. 1984), Stictis carnea (Sherwood 1977), S. radiata (Wedin et al. 2006), and S. sphaeroboloides (Sherwood 1977); saprotrophic, but possibly facultatively lichenized depending on a substrate - Carestiella socia (Wedin et al. 2006); saprotrophic and clearly lichenized depending on a substrate - Stictis mollis (Wedin et al. 2006) and S. populorum (Wedin et al. 2006). However, there are still a lot of questions to the trophical strategies of these taxa to be solved using special methods. For instance, it is not clear yet, if the lichenized Stictidaceae, use photobiont as the only source of nutrients, or they get organic compounds also from the substrate (e. g. bark of tree).

Our research clearly shows importance of the collaboration between mycologists and lichenologists to study trophically complex taxa and to gain a better understanding of fungal diversity.

\section{ACKNOWLEDGEMENTS}

The work was carried out in the frame of the institutional research projects no. AAAA-A19-119020690077-4 (work by SCh, LK, IS, EK, DH) and no. AAAA-A19-119020890079-6 (EP) of the Komarov Botanical Institute RAS, no. AAAAA17-117062710098-4 (IG) of the Federal Scientific Center of East Asian Terrestrial Biodiversity FEB RAS, and the project 'Cryptogamic biota of Pacific Asia: taxonomy, biodiversity, species distribution' of the Botanical Garden-Institute FEB RAS (SCh, LK, AE). The study was partly supported by the Russian Foundation for Basic Research (grant no. 1804-00098, AE; grant no. 18-05-60093 SCh, DH, LK, EK, IS) and no. 19-54-50010 RFBR together with Japan Society for the Advancement of Science; SCh, AE, IG).

\section{LITERATURE CITED}

Churakov, B.P., E.S. Huseyin, F. Selcuk, K.E. Kornilin \& T.A. Romanova 2015. Preliminary synopsis of biota of micromycetes of forests of the Ulyanovsk region. In: Biodiversity and ecology of fungi and fungus-like organisms northern Eurasia (A.V. Mukhin, ed.), pp. 273-276, Yekaterinburg, publishing house of the Ural University (in Russian). [Чураков Б.П., Хусейн Э.С., Сельчук Ф., Корнилин К.Е., Романова Т.А. 2015. Предварительный

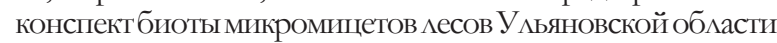
/ / Биоразнообразие и экология грибов и грибоподобных организмов северной Евразии. Екатеринбург: Издательство Уральского университета. С. 273-276].
Culberson, W.L. 1972. Disjunctive distributions in the lichenforming fungi. Annals of the Missouri Botanical Garden 59(2): 165-173.

Czerepanov, S.K. 1995. Vascular plants of Russia and adjacent states (The Former USSR). Cambridge, New York, Melbourne, Cambridge University Press, 516 pp.

DiCosmo, F., T.R. Nag Rag \& W.B. Kendrick 1984. A revision of the Phacidiaceae and related anamorphs. Mycotaxon 21:1-234.

Davidse, G. 1983. Biogeographical relationships between temperate eastern Asia and temperate eastern North America: the twenty-ninth annual systematics symposium. Annals of the Missouri Botanical Garden 70:421-422.

Dudka, I.O., V.P. Heluta, T.V. Andrianova, V.P. Hayova, Yu.Ya. Tykhonenko, M.P. Prydiuk, Yu.I. Holubtsova et al. 2009. Fungi of the nature reserves and national nature parks of Eastern Ukraine, vol. 1. Aristey, Kyiv, 306 pp. (in Ukrainian). [Аудка I.О., Гелюта В.П., Андріанова Т.В., Гайова В.П., Тихоненко Ю.Я., Придюк М.П., Голубцова Ю.І. и Ар. 2009. Гриби заповіАників та національних природних парків \івобережної України. Київ: Арістей. Т. 1. 306 с.].

Fries, E.M. 1823. Systema Mycologicum, sistens fungorum ordines, genera et species, huc usque cognitas qas ad normam methodi naturalis determinavit, disposuit atque descripsit. Lundae: ex officina Berlingiana 2(2):275-621.

Gamundí, I.J., D.W. Minter, A.I. Romero, V.A. Barrera, A.L. Giaiotti, M.I. Messuti \& M. Stecconi 2004. Checklist of the Discomycetes (Fungi) of Patagonia, Tierra del Fuego and adjacent Antarctic areas. Daminiana 42(1-4):63-164.

Graham, A. 1972. Outline of the origin and historical recognition of floristic affinities between Asia and eastern North America. In: Floristics and Paleofloristics of Asia and Eastern North America (Graham, A., ed.), pp. 1-18. Elsevier, Amsterdam.

Hawksworth, D. 2015. Lichenization: The origins of a fungal life-style. In: Recent advances in lichenology: Modern methods and approaches in lichen systematics and culture techniques, vol. 2, (Upreti, D.K., Divakar, P.K., Shukla, V., Bajpai, R., eds), pp. 1-10. Springer, New Delhi.

Hermansson, J., T.N. Pystina, B. Ove-Larsson \& M.P. Zhurbenko 2006. Lichens and lichenicolous fungi of the Pechoro-Ilychsky Nature Reserve. Flora i fauna zapovednikov 109: 1-79 (in Russian). [Херманссон Я., Пыстина Т.Н., Ове-Аарссон Б, Журбенко М.П. 2006. Аишайники и михенофильные грибы Печеро-Илычского заповедника // Фцора и фауна заповедников. Вып. 109. С. 1-79].

Himelbrant, D.E., I.S. Stepanchikova, J. Motiejūnaite, J.V. Gerasimova, E.S. Kuznetsova, A.V. Dyomina \& A.G. Tsurykau 2017. New records of lichens and allied fungi from the Leningrad Region, Russia. VIII. Folia Cryptogamica Estonica 54:63-70.

Huseyin, E.S., F. Selcuk, B.P. Churakov, K.E. Kornilin \& T.A. Romanova 2016. Microfungi on forest trees and shrubs of Duzce Province (Turkey) and Ulyanovsk Region (Russia). Mikologiya i Fitopatologiya 50(1):35-42 (in Russian with English summary). [Хусейин Э.С., Сельчук Ф., Чураков Б.П., Корнилин К.Е., Романова Т.А. 2016. Микромицеты деревьев и кустарников месов провинции АюзАже (Турция) и У Һьяновской области (Россия) // Микология и фитопатология. Т. 50, вып. 1. С. 35-42].

Jaczewski, A.A. 1895. A catalog of mushrooms from Smolensk province, collected in 1892 and 1894. Bulletin de la Société Impériale des Naturalistes de Moscon 9:128-148 (in Russian). [Ячевский А.А. 1895. Каталог грибов Смоменской губернии, собранных в 1892 и 1894 годах // Bulletin de la Société Impériale des Naturalistes de Moscou. T. 9. C. 128-148]. 
Jaczewski, A. 1896. III Série de Matériaux pour la Flore Mycologique du gouvernement de Smolensk. Bulletin de la Société Impériale des Naturalistes de Moscon 10(1):65-94.

Johnston, P.R. 1983. Stictis and its anamorphs in New Zealand. New Zealand Journal of Botany 21:249-279.

Karsten, P.A. 1866. Enumeratio fungorum et myxomycetum in Lapponia orientali aestate 1861 lectorum. Notiser ur Sällskapets pro Fauna et Flora Fennica förhandlingar 8:193-224.

Konoreva, L.A., S.V. Chesnokov \& E.A. Davydov 2016. Stictis and Schizoxylon (Stictidaceae, Ostropales) in Russia. Herzogia 29(2):706-711.

Kovacs, G.M., J.M. Trappe, A.M. Alsheikh, K. Bóka \& T.F. Elliott 2008. Imaia, a new truffle genus to accommodate Terfezia gigantea. Mycologia 100(6):930-939.

Koval', E.Z. 1972. Mycoflora of the reserve of "Kedrovaja pad". In: Flora and vegetation of the reserve "Kedrovaja pad" (P.G. Gorovoi, ed.), pp. 105-144 (in Russian). [Коваль Э.3. 1972. Микофлора заповедника «Кедровая Падь»// ФАора и растительность заповедника «Кедровая Падь» / под реА. П.Г. Горового. С. 105-144].

Kozhevnikov, A.E. \& Z.V. Kozhevnikova 2014. Taxonomic composition and special features of the natural flora in the Primorsky Territory. V.L. Komarov Memorial Lectures 62:762 (in Russian with English summary). [Кожевников А.Е., Кожевникова 3.В. 2014. Таксономический состав и особенности природной флоры Приморского края // Комаровские чтения. Вып. 62. С. 7-62].

Kuznetsova, E.S., J. Motiejūnaite, I.S. Stepanchikova, D.E. Himelbrant \& P. Czarnota 2012. New records of lichens and allied fungi from the Leningrad Region, Russia III. Folia Cryptogamica Estonica 49:31-37.

Li, H.L. 1952. Floristic relationships between eastern Asia and eastern North America. Transactions of the American Philosophical Society 42: 371-429.

Lobik, A.I. 1928. Materials for the mycological flora of the Kum River floodland according to study of 1925. In: Materials on floristic and faunistic survey of the Tersky district, pp. 13-29 (In Russian). [Аобик А.И. 1928. Материалы к микологической флоре плавень реки Кумы по обслеАованиям 1925 года // Материалы по фмористическому и фаунистическому обследованию Терского окруra. C. 13-29].

Lücking, R., B.P. Hodkinson \& S. D. Leavitt 2016. The 2016 classification of lichenized fungi in the Ascomycota and Basidiomycota - approaching one thousand genera. The Bryologist 119(4): 361-416.

Malençon, G.\& R. Bertault 1969. Champignons du Maroc II. Bulletin de la Société des Sciences Naturelles et Physiques du Maroc 49(1-2):69-80.

Malençon, G. \& R. Bertault 1972. Champignons de la Péninsule Ibérique. IV. - Les Iles Baléares. Acta Phytotaxonomica Barcinonensia 11:1-64.

Martius, H. 1817. Prodromus florae Mosquensis. Editio altera, Lipsiae: commercio industriae. 288 pp.

Muchnik, E., L. Konoreva, S. Chesnokov, A. Paukov, A. Tsurykau \& J. Gerasimova 2019. New and otherwise noteworthy records of lichenized and lichenicolous fungi from central European Russia. Herzogia 32:111-126.

Notov, A.A., D.E. Himelbrant \& G.P. Urbanavichus 2011. The list of lichens and allied fungi of Tver Region. Tver State University, Tver, 124 pp. (in Russian with English summary). [Нотов А.А., Гимельбрант А.Е., Урбанавичюс Г.П. 2011. Аннотированный список михенофлоры Тверской области. Тверь: Тверской государственный университет. 124 с.].
Popov, E.S. \& S.V. Volobuev 2014. New data on woodinhabiting macromycetes in key protected areas of the south-western part of the non-chernozem zone. Mikologiza i fitopatologiya 48(4):229-237 (in Russian with English summary). [Попов Е.С., Волобуев С.В. 2014. Новые данные о Аеревообитающих макромицетах ключевых охраняемых природных территорий Юго-западного Нечерноземья // Микология и фитопатология. Т. 48, № 4. C. 229-237].

Popov, E.S. 2012. New data on discomycetes of the Novgorod region. In: Materials of the 2nd regional scientific-practical conference «Research and environmental activities in specially protected natural areas of the Novgorod Region», Valdai, 18-19 November 2011 (E.M. Litvinova, ed.), pp. 15-19, Velikiy Novgorod (in Russian). [Попов Е.C. 2012. Новые Аанные о Аискомицетах Новгородской области // Исследования и природоохранные действия на особо охраняемых природных территориях Новгородской области: Материалы 2-й регион. науч.-практ. конф., г. Вацдай, 18-19 ноября 2011 г. / Сост. и общ. реА. Е.М. Аитвиновой. Великий Новгород. С. 15-19].

Rodway, L. 1924. Tasmanian Discomycetes. Proceedings of the Royal Society of Tasmania 119:90-122.

Rostrup, E. 1891. Tillaeg til "Grønlands svampe (1888)". In: Conspectus florae groenlandicae. Pars tertia, (J.S. Deichmann Branth, C. Grønlund, L. Kolderup Rosenvinge \& E. Rostrup, eds.), pp. 593-643, I commission hos C.A. Reitzel, Kjøbenhavn.

Sherwood, M.A. 1977. The ostropalean fungi. Mycotaxon 5: $1-277$.

Sirko, A.V. 1976. New and interesting species of ascomycetes in the flora of Urals. Discomycetes. Novosti sistematiki nizshikh rastenii 13:120-126 (in Russian). [Сирко A.B. 1976. Новые и интересные виды сумчатых грибов во флоре Урала. Аискомицеты // Новости систематики низших растений. Т. 13. С. 120-126].

Smith, C.W., A. Aptroot, B.J. Coppins, A. Fletcher, O.L. Gilbert, P.W. James, \& P.A. Wolseley 2009. The lichen flora of Great Britain and Ireland. British Lichen Society, London. $1046 \mathrm{p}$.

Thümen, F. 1880. Beiträge zur Pilzflora Sibiriens. IV. Bulletin de la Societe Imperiale des Naturalistes de Moscou 55(2):198-233.

Tranzschel, W. 1905. Materials for mycological flora of Russia. List of fungi collected in the Crimea. II. Travaux du Musee Botanique de l'Academie Imperiale des Sciences de St.-Peterbourg 2:31-47 (in Russian). [Траншемь В. 1905. Материалы Аля микологической фморы России. Список грибов, собранных в Крыму. II / / Труды Ботанического Музея Императорской Академии Наук. Вып. 2. С. 31-47].

Tranzschel, W. 1914. Die Pilze und Myxomyceten Kamtschatka's. In: Expedition à Kamtchatka organisée par Th. P. Riabouchinsky avec le concours de la Société Impériale Russe de Géographie. Section de Botanique, vol. 2, pp. 535-576, Moscow.

Tranzschel, W. \& I. Serebrianikow 1912. Mycotheca Rossica, sive Fungorum Rossiae et regionum confinium Asiae specimina exsiccata, fasc. 6-7. Jaroslawl.

Urbanavichene, I.N. 2011. First data on lichens of Zyuratkul national park (Chelyabinsk Region). Novosti sistematiki niashikh rastenii 45:223-236 (in Russian with English summary). [Урбанавичене И.Н. 2011. Первые сведения о мишайниках национального парка «Зюраткуль» (Челябинская область) // Новости систематики низших растений. Т. 45. С. 223-236].

Urbanavichene, I.N. \& G.P. Urbanavichus 2014. Contribution to the lichen flora of the Achipse River valley (SW Caucasus, Krasnodarsky Kray). Novosti sistematiki niæshikh rastenii 
48:315-326 (in Russian with English summary). [Урбанавичене И.Н., Урбанавичюс Г.П. 2014. К михенофморе Аолины реки Ачипсе (Юго-Западный Кавказ, Краснодарский край) / / Новости систематики низших растений. Т. 48. С. 315-326].

Urbanavichus, G.P. 2014. Additions to the lichen flora of Murmansk region. Byulleten' Moskouskogo Obshchestva Ispytatelei Prirody Otdel Biologicheskii 119(3):77 (in Russian). [Урбанавичюс Г.П. 2014. Аополнения к михенофлоре Мурманской области // Бюлметень Московского общества испытателей природы. ОтАел биологический. T. 119, вып. 3. С. 77].

Urbanavichus, G.P. \& I.N. Urbanavichene 2015. A contribution to the lichen flora of Utrish Nature Reserve. Turczani nowia 18(2):86-95 (in Russian with English summary). [У банавичюс Г.П., Урбанавичене И.Н. 2015. Материалы к михенофморе заповедника «Утриш» // Turczaninowia. T. 18, №2. C. 86-95].

Urbanavichus, G.P. \& I.N. Urbanavichene 2017. Contribution to the lichen flora of Erzi Nature Reserve, Republic of Ingushetia, North Caucasus, Russia. Willdenowia 47(3):227-237.

Vaasma M., K.A. Kalamees \& A. Raitviyr 1986. Macromycetes of the Caucasian State Reserve. Valgus, Tallin, 106 pp. (in Russian). [Ваасма М., Каламеэс К. А., Райтвийр А. 1986. Макромицеты Кавказского государственного заповеАника. Тамлин: Валгус, 106 с.].

Vasil'eva, L.N. 1939. Fungi of the Caucasian reserve. Uchyonye zapiski kazanskogo gosudarstvennogo universiteta imeni V.I. Ul'yanova-Lenina 99(1):1-66 (in Russian). [Васильева А.Н. 1939. Грибы Кавказского заповедника // Учёные записки Казанского государственного университета им. В.И. УАьянова-Аенина. Т. 99, № 1. С. 1-66].

Vasilyeva, L.N. \& S.L. Stephenson 2010. Biogeographical patterns in pyrenomycetous fungi and their taxonomy. 1. The Grayan disjunction // Mycotaxon 114:281-303.

Wedin, M., H. Döring \& G. Gilenstam 2004. Saprotrophy and lichenization as options for the same fungal species on different substrata: environmental plasticity and fungal lifestyles in the Stictis-Conotrema complex. The New Phytologist 164:459-465.

Wedin, M., H. Döring \& G. Gilenstam 2006. Stictis s. lat. (Ostropales, Ascomycota) in northern Scandinavia, with a key and notes on morphological variation in relation to lifestyle. Mycological research 110:773-789.

Wedin, M., H. Döring, K. Könberg \& G. Gilenstam 2005. Generic delimitations in the family Stictidaceae (Ostropales, Ascomycota): the Stictis-Conotrema problem. The Lichenologist 37(1):67-75.

Weinmann, J.A. 1828. Enumeratio Fungorum in agro Pawlowskiensi praecipue crescentium. Sylloge plantarum novarum itemque minus cognitarum 2:82-118.

Wen, J. 1999. Evolution of eastern Asian and eastern North American disjunct pattern in flowering plants. Annual Review of Ecology and Systematics 30:421-455.

Whitton, S.R., K.D. Hyde \& E.H.C. McKenzie 1999. Microfungi on the Pandanaceae, a new species of Stictis. Fungal Diversity 2:169-174.

Wu, Q. \& G. M. Mueller 1997. Biogeographic relationships between the macrofungi of temperate eastern Asia and eastern North America. Canadian Journal of Botany 75(12): 2108-2116.

Zervakis, G., P. Lizon, D. Dimou \& E. Polemis 1999. Annotated check-list of the Greek macrofungi. II. Ascomycotina. Mycotaxon 72:487-506. 